\title{
A new variety of Cleistanthus (Phyllanthaceae) from southern Western Ghats, India
}

\author{
Girishkumar E. ${ }^{\text {* }}$ \& P. Sunojkumar ${ }^{2}$ \\ ${ }^{1}$ Post Graduate Department of Botany, Mahatma Gandhi Government Arts College, Mahe, \\ Union Territory of Puducherry - 673 311, India \\ ${ }^{2}$ Department of Botany, University of Calicut, Malappuram District, Kerala - 673 635, India \\ *E-mail: girishkzd@gmail.com
}

\begin{abstract}
A new variety, Cleistanthus travancorensis Jabl. var. jaleelianus E.Girish \& Sunojk. (Phyllanthaceae) is described here from the riparian system of Kuppam River of Kannur district in southern Western Ghats of India. The new variety differs from other two varieties mainly by its relatively longer acumen of the leaves, undulate leaf margins, longer petioles, larger bracts and the inflorescences borne on special small leaved branches. Detailed description, photographs and a table showing the diagnostic characters are provided for easy identification of this taxon.
\end{abstract}

Keywords: Kannur, Kerala, Riparian system.

\section{Introduction}

The genus Cleistanthus Hook.f. ex Planch. is represented by more than 100 species, of which about 30 species are occurring in Africa and Madagascar and the rest in tropical Asia, from Sri Lanka and India to N. Australia and Melanesia (Chakrabarty \& Balakrishnan, 2018; Mabberley, 2017). Cleistanthus is represented by eight species in India, of which five are endemic (Chakrabarty et al., 2002). Among the Indian endemics, C. andamanicus N.Balach., Gastmans \& Chakrab. and C. balakrishnanii Chakrab. are found in the Andaman and Nicobar Islands, whereas C.nokrensis B.Singh is restricted to Northeast India. Two species, viz. C. malabaricus Müll.Arg., and C. travancorensis Jabl. are seen towards the southern

Received: 06.01.2020; Revised \& Accepted: 31.01 .2020 Published Online: 30.06 .2020 and western parts of India. Sivarajan and Balachandran (1985) described C. sankunnianus Sivar. \& Balach. from plants under cultivation in the Herbal Garden of Arya Vaidya Sala, Kottakkal, Kerala and this has been later reduced to a variety of $C$. travancorensis by Udayan and Chakrabarty (2012).

During a taxonomic survey of the riparian flora of the Kuppam River in southern Western Ghats, the first author noticed an interesting population of Cleistanthus from Rayarome area at Kannur district in Kerala state at an elevation of about 30 feet above sea level. A few plants were also observed in another riparian zone near Manikkal Bridge, nearly $5 \mathrm{~km}$ away from the first collection. Natural growth and flowering of these populations were observed for two years and the plants were identified as C. travancorensis with a few distinct characteristic features. The morphology of the newly collected specimens were compared with live and herbarium specimens including types of C. travancorensis deposited at various Indian herbaria (CAL, CALI, $\mathrm{K}, \mathrm{MH}$ and TBGT). Further, the keys provided in recent literature (Balakrishnan \& Chakrabarty, 2007; Singh et al., 2014; Chakrabarty \& Balakrishnan, 2018) were also cross checked. This enabled us to conclude that the new populations represent a new variety of C. travancorensis which is described here. Photographic images of live plants (Fig. 1) and a comparison chart (Table 1) depicting the morphological differences of three varieties of $C$. travancorensis are provided for easy identification.

Cleistanthus travancorensis Jabl. var. jaleelianus E.Girish \& Sunojk., var. nov.

Fig. 1 


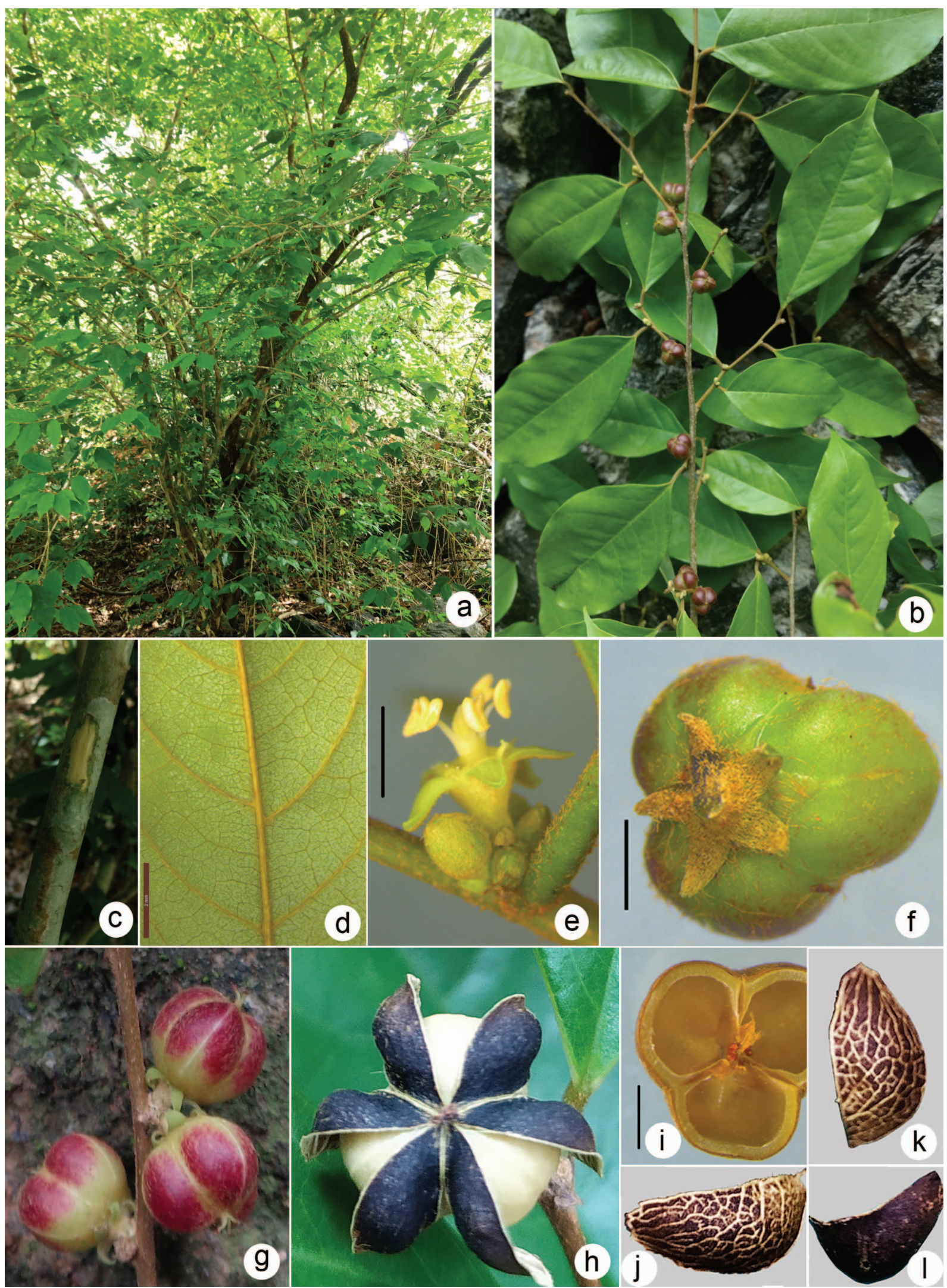

Fig. 1. Cleistanthus travancorensis Jabl. var. jaleelianus E.Girish \& Sunojk.: a. Habit; b. Fruiting twig; c. Stem blaze; d. Leaf - abaxial surface; e. Male flower - side view; f. Young fruit; g. Mature fruits; h. Dehiscing capsule; i. T.S. of fruit; j \& k. Inner surface of epicarp; I. Dry perciarp outer surface (from Girishkumar 455; photos by E. Girishkumar; scale bar: 2 mm). 
Cleistanthus travancorensis var. jaleelianus is similar to var. travancorensis and var. sankunnianus (Sivar. \& Balach.) Udayan \& Chakrab., but differs in the relatively longer acumen of the leaves, undulate leaf margins, longer petioles, larger bracts and the inflorescences borne on special small leaved branches. It can be further distinguished from var. travancorensis by its shorter stipules (Table 1).

Type: INDIA, Kerala, Kannur district, Rayarome, Kuppam river riparian vegetation near Rayarome bridge, on the way to Taliparamba-Coorg road, $\mathrm{N}$ $12^{\circ} 20^{\prime} 87^{\prime \prime}$, E 7543'16", 9 m, 10.06.2018, E. Girishkumar 449 (holo CALI; iso MH).

Bushy shrubs, 2.5-4.5 m tall, profusely branched, forming a clustered canopy. Roots tucked with rocky soil of riparian zone. Stem cylindrical, predominantly smooth, peeling occasionally, bark greyish with white patches, blaze creamy-white; branches mainly horizontal and slightly drooping, terete, greyish to brownish-white with lenticels; branchlets terete, brownish or brownish-green or greenish with fusiform lenticels, slightly zigzag, with sparse appressed rufous hairs. Stipules linear, 1-1.25 mm long, pubescent. Leaves alternate; petiole $5-7 \times 1.2-1.5 \mathrm{~mm}$, with tawny pubescence; blade obovate or oblanceolate to elliptic, size varying, generally $7.5-15 \times 2.5-7 \mathrm{~cm}$, smaller towards branchlets $($ c. $5.5 \times 1.5 \mathrm{~cm})$, prominently chartaceous to slightly coriaceous, bifarious, slightly drooping, acute or cuneate at base, rarely rounded, sometimes oblique, margin slightly undulate with 4-6 undulations, acuminate or rarely acute at apex, acumen 1.5-2.75 cm long, adaxial surface glabrous, light green or yellowish green when young, dark green when mature, abaxial surface dull green, sparsely pubescent on midrib and lateral veins and rarely on lamina, venation pinnately reticulate, lateral veins usually 6-10 pairs, not prominent towards apex, veinlets prominent on abaxial surface. Cymes axillary, sessile, 2-3-flowered, either male or female on branchlets bearing smaller leaves, protandrous; bracts linear-triangular, 1-1.5 mm long, puberulous. Staminate flower c. $4 \mathrm{~mm}$ in diam. when open, sub-sessile; sepals 5, triangular to ovate, 1.8-2 mm long, yellowish-green, slightly spatulate, broadly acute, inner surface with longitudinal stripes, outer surface tawny pubescent; tube cupular; petals 5 , broad, triangular to orbicular, c. $0.4 \mathrm{~mm}$

Table 1. Comparison between C. travancorensis var. travancorensis, var. sankunnianus and var. jaleelianus.

\begin{tabular}{|l|l|l|l|}
\hline Characters & var. travancorensis Jabl. & $\begin{array}{l}\text { var. sankunnianus } \\
\text { (Sivar. \& Balach. } \\
\text { Udayan \& Chakrab. }\end{array}$ & $\begin{array}{l}\text { var. jaleelianus E.Girish \& } \\
\text { Sunojk. }\end{array}$ \\
\hline Pubescence of branchlets & $\begin{array}{l}\text { Rufous-velutinous or } \\
\text { tomentellous, later glabrous }\end{array}$ & $\begin{array}{l}\text { Tawny-tomentose or } \\
\text { rusty villous }\end{array}$ & Sparsely rufous pubescent \\
\hline Leaf size & $5-12 \times 1.5-6 \mathrm{~cm}$ & $3.5-8 \times 1-3 \mathrm{~cm}$ & $7.5-15 \times 2.5-7 \mathrm{~cm}$ \\
\hline Leaf apex and margins & $\begin{array}{l}\text { Acuminate or attenuate, } \\
\text { margins entire }\end{array}$ & $\begin{array}{l}\text { Acute or shortly acuminate } \\
\text { margins entire }\end{array}$ & $\begin{array}{l}\text { Acuminate or mostly } \\
\text { caudate, margins slightly } \\
\text { undulate }\end{array}$ \\
\hline Acumen length & $5-15 \mathrm{~mm}$ & $0-5 \mathrm{~mm}$ & $5-27$ mm \\
\hline No. of lateral veins & $5-11$ pairs & $5-7$ pairs & $6-10$ pairs \\
\hline Petiole length and nature & $\begin{array}{l}2-3 \mathrm{~mm}, \text { velutinous to } \\
\text { glabrous }\end{array}$ & $1-3 \mathrm{~mm}$, rusty villous & $\begin{array}{l}5-7 \mathrm{~mm} \text {, ribbed with tawny } \\
\text { pubescence }\end{array}$ \\
\hline Stipule length & $3-5 \mathrm{~mm}$ & $1-3 \mathrm{~mm}$ & $1-1.25 \mathrm{~mm}$ \\
\hline Flower position & $\begin{array}{l}\text { On main and lateral } \\
\text { leafy branches }\end{array}$ & On main branches & $\begin{array}{l}\text { On small leaved branchlets, } \\
\text { rarely on main leafy branch }\end{array}$ \\
\hline Ovary & $\begin{array}{l}\text { Tawny or ochraceous } \\
\text { villous }\end{array}$ & Glabrous & $\begin{array}{l}\text { Sparsely appressed rufous } \\
\text { hairy }\end{array}$ \\
\hline Capsules & $3-5 \times 4-6$ mm & $c .6 \times 8 \mathrm{~mm}$ & $5-6 \times 7-8$ mm \\
\hline
\end{tabular}


long, gelatinous white, apex slightly cuspidate; disc yellow, annular, flat with wavy margin; stamens 5 , filaments $c .2 \mathrm{~mm}$ long, white; anthers $c .1 \mathrm{~mm}$ long, extrorse, longitudinally dehiscing; pistillode at the centre with a conical tip, sparsely hairy. Pistillate flowers axillary, c. $5 \mathrm{~mm}$ in diam., sessile, sepals, petals and disc same as in staminate flowers, ovary subglobose, covered with appressed hairs, 3(-4)-locular, locules biovulate; styles 3 (or 4), 1-1.5 mm long, bifid at apex for c. $0.5 \mathrm{~mm}$. Capsules prominently 3lobed, globose, slightly depressed, c. $6 \times 8 \mathrm{~mm}$, subtended by persistent sepals curling outwards, covered with sparse appressed rufous hairs, greenish purple when young, dark purple on maturity, black when dry; dehiscence loculicidal, partly septicidal, pericarp detaches to expose three cream coloured cocci, inner surface of pericarp with reticulate ornamentations, each coccus $c .5 \times 4 \mathrm{~mm}$ with single seed in each; seed c. $4 \times 3 \mathrm{~mm}$, trigonous with a notch on one side.

Flowering \& fruiting: Flowering starts in March and fruits are set from July to August.

Etymology: The varietal epithet 'jaleelianus' is in honour of Late Dr. V. Abdul Jaleel (Assistant Professor, Sir Syed College, Taliparamba, Kannur, Kerala), the research supervisor of the first author and a known field taxonomist who passed away at a younger age.

Habitat: Found growing amongst the rocky, flood plain region of the Kuppam River.

Distribution: Hitherto known only from Kannur district in Kerala.

Specimens examined: INDIA, Kerala, Kannur district, Taliparamba-Coorg Road, Manikkal bridge, N 12¹7'95", E 7541'52", 9 m, 14.05.2018, E. Girishkumar 499 (CALI); Rayarome, 17.06.2018, E. Girishkumar 455, 458 (Herbarium, Sir Syed College, Kannur, Kerala).

Conservation status: Two scattered populations of Cleistanthus travancorensis var. jaleelianus were observed in flood plain zones of the riparian system of Kuppam river and the recent flood that lambasted in these locations is an imminent threat to these populations. As per IUCN Criteria (2017), this variety can be included in the 'DD Category (Data Deficient)' as further exploration is needed to assess its size and range of distribution.

\section{Acknowledgements}

The first author is indebted to Head of the Department of Botany, Mahatma Gandhi Government Arts College, Mahe and the Principal, Sir Syed College, Taliparamba, Kannur District, Kerala, India for providing facilities and support. We are indebted to Dr. Tapas Chakrabarty, Scientist (Retd.), Botanical Survey of India, Kolkata, for critical analysis and confirming the novelty of the specimen.

\section{Literature Cited}

BALAKRISHNAN N.P. \& T. CHAKRABARTY 2007. The family Euphorbiaceae in India: A synopsis of its profile, taxonomy and bibliography. Bishen Singh Mahendra Pal Singh, Dehra Dun, India. p. 500.

CHAKRABARTY T. \& N.P. BALAKRISHNAN 2018. Indo-Burmese Phyllanthaceae, a taxonomic revision. Bishen Singh Mahendra Pal Singh, Dehra Dun, India. p. 437.

CHAKRABARTY T., GANGOPADHYAY M. \& N.P. BALAKRISHNAN 2002. The genus Cleistanthus Hook.f. ex Planch. (Euphorbiaceae) in the Indian subcontinent. Journal of Economic and Taxonomic Botany 26: 331-345.

IUCN Standard and Petitions Subcommittee 2017. Guidelines for using the IUCN Red List Categories and Criteria, Version 13. Available at: http://www.iucnredlist.org/ documents/RedListGuidelines.pdf (Accessed on 15.12. 2019).

MABBERLEY D.J. 2017. Mabberley's plant-book: a portable dictionary of the plants. Fourth Edition. Cambridge University Press, Cambridge. p. 1102. https://doi.org/ 10.1017/9781316335581.001

SINGH B., BORTHAKUR S.K. \& S.J. PHUKAN 2014. Cleistanthus nokrensis (Euphorbiaceae), a new species from Indian Himalaya. Taiwania 59(3): 197-205. http:// doi.org/10.6165/tai.2014.59.197

SIVARAJAN V.V. \& I. BALACHANDRAN 1985. Cleistanthus sankunnianus, a new species of Euphorbiaceae from India. Kew Bulletin 40(1): 121-123. https://doi.org/ 10.2307/4108485

UDAYAN P.S. \& T. CHAKRABARTY 2012. Euphorbiaceae. In: BALAKRISHNAN N.P., CHAKRABARTY T., SANJAPPA M., LAKSHMINARSIMHAN P. \& P. SINGH (eds.), Flora of India Volume 23: Loranthaceae to Daphniphyllaceae. Botanical Survey of India, Kolkata. p. 390. 